\title{
The Suspected Contradictory Role of Parental Care in the Adaption of Planktonic Calanoida to Temporary Freshwater
}

\author{
Genuario Belmonte
}

check for updates

Citation: Belmonte, G. The Suspected Contradictory Role of Parental Care in the Adaption of Planktonic Calanoida to Temporary Freshwater. Water 2021, 13, 100. https:/ / doi.org/10.3390/w13010100

Received: 27 November 2020 Accepted: 29 December 2020 Published: 4 January 2021

Publisher's Note: MDPI stays neutral with regard to jurisdictional clai$\mathrm{ms}$ in published maps and institutional affiliations.

Copyright: (C) 2021 by the author. Licensee MDPI, Basel, Switzerland. This article is an open access article distributed under the terms and conditions of the Creative Commons Attribution (CC BY) license (https:// creativecommons.org/licenses/by/ $4.0 /)$.
Laboratory of Zoogeography and Fauna, DiSTeBA, Campus Ecotekne, University of Salento, 73100 Lecce, Italy; genuario.belmonte@unisalento.it

\begin{abstract}
Calanoida have the highest number of species among Copepoda in marine plankton, but not in fresh water, where the greatest number are Cyclopoida. Freshwater Cyclopoida also live in more freshwater sites than Calanoida. This could be a consequence of an invasion of freshwater by marine Cyclopoida before Calanoida. Similar to Cyclopoida, but different from marine Calanoida, freshwater Calanoida females produce egg sacs and care for eggs. This strategy is common among all freshwater plankton, suggesting that the evolution of parental care is an obliged adaption to conquer fresh water. Calanoida, different from Cyclopoida, survive adverse conditions as resting eggs. This life-cycle constraint obliges eggs to survive their mother's death and wait in the benthos for a certain period. The necessity of completing embryonic development and the hatching of eggs far from the mother's protection may be responsible for the relatively lower evolutionary success of Calanoida in fresh water compared to Cyclopoida (which rest as juveniles, thus protecting eggs in any moment of their development). Therefore, the brooding of eggs appears to be the obliged solution for Calanoida's final establishment in fresh water, but the dispersion of eggs on the bottom after the mother's death and during the rest period is probably the weak point in Calanoida's competition with Cyclopoida.
\end{abstract}

Keywords: adaption; brooding; parental care; Calanoida; freshwater zooplankton

\section{Introduction}

Calanoida are the most successful taxon of Copepoda in marine plankton in terms of number of species. This is not true in fresh water, where the greatest number of Copepoda species belong to Cyclopoida. Only one Calanoida family, Diaptomidae, is exclusive to fresh water, where it is represented by 530 species grouped in 63 genera [1]. Diaptomidae belong to the superfamily Diaptomoidea, which contains six additional families. They are the only Calanoida represented in inland waters and estuaries at the sea-land border. Boxshall and Jaume [2] assumed that Copepoda evolved in marine waters and suggested that the time elapsed since the colonization of fresh water by a lineage of Copepoda is directly correlated with the species richness shown for that lineage in the new environment. In addition, the same authors suggest that one family could be considered as roughly corresponding to a single colonization wave from marine waters. Diaptomidae (quasi-absent from Australia) represent a colonization wave that gave origin to freshwater Calanoida after the separation of boreal landmasses from Gondwana, no more than about 160 million years ago. Accepting such an interpretation, the higher adaptive establishment of freshwater Cyclopoida, which has 924 species in all the continents, according to [1], all of which belong to the single family Cyclopidae, is probably due to a preceding colonization wave from the marine environment in a period before the break-up of Pangea more than 190 million years ago. It is evident to the cited authors that the high number of Cyclopidae could be due to the longer evolutionary time available to them in fresh water.

Regarding the comparison with a marine environment, marine Calanoida represent a number of species about double that of Cyclopoida [3]. In addition, Cyclopoida inhabit 
more than $95 \%$ of inland waters, while Calanoida are reported in less than $50 \%$ of inland water sites (Table 1).

Table 1. Planktonic copepods. Some examples of species richness reported in marine and inland waters in areas of different geographic extension. (Data from references: [3-8]; and Walsh, personal communication).

\begin{tabular}{|c|c|c|c|c|c|c|c|c|}
\hline \multirow{3}{*}{ Copeopod } & \multicolumn{8}{|c|}{ Number of Species } \\
\hline & \multicolumn{2}{|c|}{ Marine Waters } & \multicolumn{6}{|c|}{ Inland Waters } \\
\hline & $\begin{array}{l}\text { Western } \\
\text { Mediter- } \\
\text { ranean }\end{array}$ & $\begin{array}{c}\text { Adriatic } \\
\text { Sea }\end{array}$ & Europe & Italy & Mexico & Florida & Malaysia & Australia \\
\hline Calanoida & 310 & 181 & 95 & 31 & 15 & 3 & 11 & 41 \\
\hline Cyclopoida & 124 & 90 & 210 & 100 & 48 & 41 & 28 & 120 \\
\hline References & [3] & [3] & [4] & [5] & [6] & [7] & [8] & Walsh \\
\hline
\end{tabular}

The scheme can be locally disregarded in the case of Canadian lakes, where Calanoida species are reported as more abundant than Cyclopoida $[9,10]$. That situation, however, could correspond to a nonequilibrium state due to the relatively young age of the system (see [11] for a discussion of the role of time in the evolution of species numbers).

While both are Copepoda, planktonic Cyclopoida and Calanoida would likely not be perfectly similar in adaptive strategies, and differences in their evolutionary success could also derive from such differences rather than from a different adaption time.

\section{Reproductive Traits Typical of Freshwater Calanoida}

Diaptomidae can be considered to represent the Calanoida model of adaptive solutions to living in a freshwater environment. Diaptomidae, similar to other Diaptomoidea, but different from most other Calanoida, produce resting eggs, which allow species to survive adverse periods [12]. This life-cycle trait is fundamental for establishment in variable habitats (even temporary) as the freshwater ones. However, resting cannot represent the only solution because the rest capability is widespread in marine Calanoida, without allowing all lineages to successfully colonize fresh water. Resting among Calanoida could be typical of different life-cycle stages [13], but when considering only resting eggs, not all taxa with this feature successfully invaded freshwater.

On the other hand, the rest capability of freshwater Cyclopidae, which have been more successful than Diaptomidae, is not exhibited by eggs, but by the copepodite stage [14].

These facts suggest that the success of Diaptomidae in invading fresh waters relies not simply upon a resting stage, but also upon solving other problems, the most important in my opinion being the survival of the late embryo and the early life-cycle stage (the nauplius).

If we focus our attention on reproductive traits, we perceive an evident sexual dimorphism among Diaptomoidea, with adult males of each species sensibly smaller than females (compared to marine Calanoida), and equipped with a modified right antennule for grasping the female during mating.

The larger size of females in freshwater species could be imposed by the presence of a large egg sac, a trait absent in marine species. The egg sac is the evident common characteristic shared with planktonic Cyclopoida and with all freshwater zooplankton. In fact, Rotifera and Cladocera, which dominate the freshwater zooplankton together with Copepoda, both show extreme sexual dimorphism (with smaller or completely absent males), and enhancement of parental care by brooding few large eggs that hatch directly into juveniles. The investment in early-stage protection by Rotifera and Cladocera is a tradeoff that results in a lower number of embryos per female. However, these invertebrates, balance the reduction of eggs per female with the ability to reproduce via parthenogenesis, thus maximizing the number of females in each population. 
Diaptomidae are phylogenetically distant from Cladocera, and even more distant from Rotifera; they show populations with a sex ratio close to 1:1 and never engage in parthenogenesis. The presence of a large part of the population (males) that does not directly produce descendants is balanced by an enhancement of female fecundity. The high number of embryos produced by each female are brooded in an egg sac, thus requiring larger females that are able to actively avoid sinking due to the additional ballast of many eggs, which are negatively buoyant.

In general, among Calanoida, species with an egg sac have a lower egg-production rate per female [15]. A true egg sac is an exceptional feature in off-shore marine species, and it is common only in brackish water and lagoon species. An "apron" of unknown significance has been reported for fertilized mature females of some Acartiidae (Diaptomoidea typical of brackish water), although it does not have any involvement in egg protection $[16,17]$. The production of a true egg sac in Diaptomidae, Temoridae, and Centropagidae-all of which successfully invaded fresh water-is a reliable indication of its value in the establishment of Calanoida in freshwater habitats.

Among Centropagidae, only freshwater species (e.g., those of the genera Boeckella, Calamoecia, Limnocalanus, and Sinocalanus) have an egg sac, and not the marine ones. The presence of an egg sac, which allows the eggs to remain in the water column together with the mother, could be interpreted as advantageous for species' establishment in freshwater environments. Eggs laid free in a freshwater environment have a high probability of reaching the bottom before they hatch, and we suspect that problems for embryos inside eggs could be due to this interaction with the bottom. Hirst and Kjorboe [18], even without an interpretation of the data, demonstrated that broadcasted eggs have a mortality rate (excluding predation) that is significantly higher than those in egg sacs.

The female-biased sexual size dimorphism of Diaptomoidea justifies the presence of a more evident modification of the right antennule (A1) of the adult male, which allows it to powerfully grasp a larger and stronger female during mating in order to complete the transmission of the spermatophore. Given the likely presence of predators in the water column, the formation of a mating pair, or tandem, of individuals has to occur quickly, and a robust $\mathrm{A} 1$ ensures a prompt grasping and eliminates the need for repetitive attempts.

The fertilized female can be re-fertilized after the completion of a cycle of egg sac production and nauplii release (about 5-6 days in Eudiaptomus gracilis) [19]. The period of tandem holding during mating varies widely, ranging from 2-4 minutes in Eudiaptomus [19] to a period of days in Eurytemora [20], which is probably due to the result of sexual versus natural selection, reflecting trade-offs between enhancement of fertilization success and the reduction of vulnerability to visual predation [21]. The realization of tandems is a sort of evolutionary obligation because it is not suppressed (although it is reduced in order to optimize survival) when visual predators (e.g., fish) are present in the environment. The reduction of mating activities can be realized either by depressing the mating frequency (with sperm storage in females), or by shortening the time spent in tandem mating [21].

In marine pelagic environments, a lighter A1 geniculation (used to grasp females smaller than the freshwater ones) in non-Diaptomoidea Calanoida males has been considered as an evolutionary solution to avoid mating for long durations in environments rich in predators [22], compensated by a smaller size dimorphism between sexes. This solution evidently did not involve the freshwater species.

Ali et al. [23] assessed the disadvantage, in terms of eggs produced, of multi-fertilized females. The larger body size of females should allow them to better impede males from attempting multiple mating. This has resulted in the amelioration of their fecundity in terms of eggs produced, and consequently, of their reproductive success.

The large size of Diaptomidae females, which is considered to be useful in the tuning of mating behavior, seems to be a pre-adaption resulting from the necessity to swim up in the water column while sustaining the additional weight of an egg sac.

The presence of an egg sac (absent in marine Calanoida), as in the case of the tandem composition, represents an obstacle for rapid escape behavior and increases individual 
visibility to predators. For this reason, the advantages deriving from an egg sac, which prevents the eggs from sinking to the bottom, have to largely exceed the disadvantages of interaction between broadcasted eggs and the bottom, the retarded mobility of egg-carrying females, and the visibility to predators of larger females and mating tandems.

In Cyclopidae, males have prehensile antennulae for grasping females during mating, and females produce eggs in paired lateral egg sacs. Additionally, sexual dimorphism in Cyclopidae is similar to that exhibited by Diaptomidae, with males sensibly smaller than females in each species. The general convergent adaption in these two taxa is the increase in body size in females, probably driven by the necessity to sustain egg sacs in the water column.

Notwithstanding all these similarities, Cyclopidae are the most successful family group of Copepoda in freshwater plankton, in terms of both number of species and number of inland water sites colonized. In fact, inland water sites without Cyclopoida species are very rare, while Calanoida generally are absent in more than $50 \%$ of the sites from which plankton have been collected (Table 2).

\section{Conclusions}

Planktonic populations of freshwater Copepoda are characterized by high numbers of nauplii, which derive from eggs when they are still in the sac attached to the mother's urosome. The rule of reduction/suppression of a free-swimming larva in freshwater invertebrates [24] appears to not be valid for freshwater Copepoda. Pennak [25] suggested that in freshwater organisms, the osmoregulation capabilities, which are necessary to cope with the highly diluted environment, require a certain level of physiological maturation during the first developmental stages (corresponding with the necessity for early stages to spend the larval stage time inside the egg envelope). Evidently, nauplii of planktonic Copepoda need not go through such a physiological maturation; they are able to avoid negative osmoregulation consequences in extremely diluted waters. At this point, the evolution of egg sacs in freshwater planktonic Copepoda seems to not be necessary for hatching advanced stages of progenies, but simply to keep the eggs from sinking to the bottom.

The predation pressure on females that carry egg sacs appears to be a risk of secondary importance, because females of freshwater Copepoda (similar to Cladocera and Rotifera) evolved protection of their eggs, irrespective of the increased visibility and retarded escape behavior that this condition could present. Conversely, the evolution of floating eggs (e.g., in Artemia), although favored by enhanced water density values (in hyperhaline ponds), can be viewed as an additional demonstration of the necessity for species to avoid the sinking of eggs to the bottom.

One explanation could be the negative effect of low temperatures and/or hypoxia/ anoxia (relatively common - at least periodically - in freshwater bottoms, if compared with values in the water column) on the early embryonic stages of Copepoda eggs [26,27]. In agreement with Kimmerer [28], who proposed that the vulnerability of individuals is inversely correlated with their developmental conditions, and that invertebrate predation on nauplii is greater than fish predation on adults, I would like to suggest an extension of this rule to the egg stage. Karlson and Viitasalo-Frosen [29] demonstrated that invertebrates of infauna and epifauna actively subtract eggs from bottom sediments in the Baltic Sea. Only an extreme vulnerability of the eggs on the bottom can justify the energetic investment of planktonic mothers in realizing and carrying an egg sac. Gentleman and Head [30], similar to [18], on the other hand, gave their attention to the general weakness of early developmental stages of larva, which do not survive without suffering predation.

The occurrence of harsh conditions in the bottom layers of water habitats is common in shallow ponds. Among Copepoda, Harpacticoida are benthic and appear well-adapted to such conditions [31]. In the case of Harpacticoida, however, the presence of egg sacs in adult females can be interpreted as a device used to avoid the eggs becoming abandoned and immobile on the bottom. 
When unfavorable conditions impact the entire water column, they are avoided by plankton through the use of resting stages, during which they stay immobile on the bottom and are largely immune to the unfavorable conditions that they can possibly encounter there. In addition, this benthic period occurs during a time when all the biota components (including predators and competitors) are impacted and obliged to rest, and any competitive and/or predatory pressure between species is suspended.

Finally, a common characteristic of resting eggs is a relative lack of sensitivity to predation due to the presence of a robust chorion that resists attacks [32], provides passive immunity to microbes [33], or even ensures an insensitivity to digestive fluids during their passage through the gut of larger predators [34].

Cyclopoida do not have resting eggs, and generally their eggs cannot pass long times in the benthos, even in the case of a free layering in the water column by respective mothers [35,36]. In fact, Cyclopoida enter a resting period as copepodites (age CIV- CV) when no eggs are produced because the females are still immature.

In Calanoida, mature females produce successive egg sacs of subitaneous eggs. When resting eggs are produced by Calanoida, these reach the bottom together within the same egg sac, or with their mother when she dies, and they remain there until the return of favorable conditions to hatch a new generation. However, this phylogenetic constraint (present in Calanoida; absent in Cyclopoida) obliges the resting eggs of Calanoida to pass a certain time of their development in the benthos before they hatch. This is a sensible difference between the two Copepoda taxa, and could be involved in their different evolutionary success in terms of adaption and number of species.

Although the success could be simply due to a different evolutionary history of Copepoda coming from the marine environment in two waves (around 160 and 190 million years ago, according [2]), the obliged permanence of eggs when resting in the benthos probably plays an additional role in the competitive weakness of Calanoida in the colonization of fresh water. During the colonization of newly formed water bodies, Cyclopoida are still the winning colonizers [37,38]. Finally, the percentage of water bodies occupied by Calanoida is very low (less than $50 \%$ ), without any apparent correlation with the abiotic conditions (Table 2).

Table 2. The presence of Calanoida in freshwater bodies of different types and origins. In the same water bodies, Cyclopoida (not reported here) are present in more than $95 \%$ of sites.

\begin{tabular}{cccc}
\hline Reference & Water Body Type Studied & Number of Sites & $\begin{array}{c}\text { Number of Sites } \\
\text { with Calanoida }\end{array}$ \\
\hline$[39]$ & alpine lakes & 170 & 82 \\
\hline$[40]$ & mountain lakes & 30 & 9 \\
\hline$[41]$ & island lakes & 250 & 65 \\
\hline$[42]$ & Artificial dams/reservoirs & 51 & 21 \\
\hline$[43]$ & lowlands lakes & 121 & 55 \\
\hline$[44]$ & medium-small ponds & 60 & 18 \\
\hline$[45]$ & soda ponds & 110 & 91 \\
\hline$[38]$ & endorheic ponds & 36 & 19 \\
\hline$[46]$ & Iceland ponds & 12 & 1 \\
\hline Total & & 881 & 402 \\
\hline
\end{tabular}

The successful colonization of Cyclopoida could be the result of the rapid appearance of reproductive individuals in just a few days, because resting copepodites reach advanced developmental stages, while Calanoida attain maturity only after weeks of complete development from nauplii born by resting eggs. 
The existence of a brooding behavior (the protection of fertilized eggs in an ovisac attached to the mother) is the common element in all the freshwater plankton taxa, including Calanoida, which rarely show this character in marine environments. This suggests that the survival and persistence of species in an aquatic habitat is not determined by the presence of pelagic predators (which, on the contrary, can easily attack females with egg sacs), but by some intense negative selection pressure that explicitly acts on the bottom against broadcasted eggs (and the early embryos inside them) of all plankton taxa. All of the hypotheses regarding this widespread situation among taxa currently derive mainly from studies on coastal marine and/or brackish water species. Laboratory studies on separate or synergistic effects of bottom conditions (abiotic and biotic) on the embryonic development of freshwater plankton are lacking. These studies are necessary to understand the sensibility of embryos in eggs, which is the principal obstacle for the successful colonization of freshwater habitats by Calanoida.

Funding: This paper was written as part of the Fauna d'Italia project to create a monography on Copepoda Calanoida.

Acknowledgments: This paper was an invited contribution at the workshop "Temporary Wetlands Future in Drylands under the Projected Global Change Scenario" held in Baeza, Spain, on 9-11 March 2020. Here I thank Robert Walsh for his indications on Australian fauna; G. Boxshall (Natural History Museum, London, UK), who agreed to discuss some points in the paper; and M. Alcaraz (Institut de Ciences del Mar, CSIC, Spain), who helpfully criticized some logic constructions.

Conflicts of Interest: Author declares no conflict of interest.

\section{References}

1. Walter, T.C.; Boxshall, G.; World of Copepods Database. World Register of Marine Species. 2020. Available online: http: //www.marinespecies.org/aphia.php?p=taxdetails\&id=149688 (accessed on 12 September 2020).

2. Boxshall, G.A.; Jaume, D. Making Waves: The Repeated Colonization of Fresh Water by Copepod Crustaceans. Adv. Ecol. Res. 2000, 31, 61-79.

3. Razouls, C.; de Bovée, F; Kouwenberg, J.; Desremaux, N. Diversity and Geographic Distribution of Marine Planktonic Copepods. 2005-2020. Available online: http:/ / copepodes.obs-banyuls.fr/en (accessed on 31 January 2020).

4. Blędzki, L.A.; Rybak, J.I. Freshwater Crustacean Zooplankton of Europe; Springer: Cham, Switzerland, 2016; p. 923.

5. Belmonte, G. Calanoida (Crustacea: Copepoda) of the Italian fauna: A review. Eur. Zool. J. 2018, 85, 274-290. [CrossRef]

6. Suarez-Morales, E.; Reid, J.W. An updated list of the free-living freshwater copepods (Crustacea) of Mexico. Southwest. Nat. 1998, $43,256-265$.

7. Bruno, M.C.; Reid, J.W.; Perry, S.A. A list and identification key for the freshwater, free-living copepods of Florida (U.S.A.). J. Crustacean Biol. 2005, 25, 384-400. [CrossRef]

8. Lim, R.P.; Fernando, C.H. A review of Malaysian freshwater Copepoda with notes on new records and little known species. Hydrobiologia 1985, 128, 71-89. [CrossRef]

9. Pinel-Alloul, B.; André, A.; Legendre, P.; Cardille, A.J.; Patalas, K.; Salki, A. Large-scale geographic patterns of diversity and community structure of pelagic crustacean zooplankton in Canadian lakes. Glob. Ecol. Biogeogr. 2013, 22, 784-795. [CrossRef]

10. Couture, S.; Hudon, C.; Gagnon, P.; Taranu, Z.; Pinel-Alloul, B.; Houle, D.; Aldamman, L.; Beauvais, C.; Lachapelle, M. Zooplankton communities in Precambrian Shield lakes (Quebec, Canada): Responses to spatial and temporal gradients in water chemistry and climate. Can. J. Fish. Aquat. Sci. 2020, In Press. [CrossRef]

11. Belmonte, G. Species richness in isolated environments: A consideration of the effect of time. Biodivers. J. 2012, 3, 273-280.

12. Belmonte, G.; Rubino, F. Resting cysts from coastal marine plankton. Oceanogr. Mar. Biol. Annu. Rev. 2019, 57, 1-88.

13. Williams-Howze, J. Dormancy in free living copepod orders Cyclopoida, Calanoida, and Harpacticoida. Oceanogr. Mar. Biol. Annu. Rev. 1997, 35, 257-321.

14. Alekseev, V.R. Diapausa Rakoobrashik. Ekologo Physiologicheskie Aspecti; Nauka Moskva: Moscow, Russis, 2019; pp. 1-144. (In Russian)

15. Ianora, A. Copepod life history traits in subtemperate regions. J. Mar. Syst. 1998, 15, 337-349. [CrossRef]

16. Belmonte, G. Diapause egg production in Acartia (Paracartia) latisetosa (Crustacea, Copepoda, Calanoida). Boll. Di Zool. 1992, 59, 363-366. [CrossRef]

17. Belmonte, G. Pteracartia a new genus of Acartiidae (Calanoida, Diaptomoidea) for Acartia josephinae Crisafi, 1974. J. Mar. Syst. 1998, 15, 359-368. [CrossRef]

18. Hirst, A.G.; Kiørboe, T. Mortality of marine planktonic copepods: Global rates and patterns. Mar. Ecol. Prog. Ser. 2002, 230, 195-209. [CrossRef] 
19. Berger, I.; Maier, G. The mating and reproductive biology of the freshwater planktonic calanoid copepod Eudiaptomus Gracilis. Freshw. Biol. 2001, 46, 787-794. [CrossRef]

20. Gauld, D.T. Copulation in calanoid copepods. Nature 1957, 180, 510. [CrossRef]

21. Jersabeck, C.D.; Luger, M.S.; Schabetsberger, R.; Grill, S.; Strickler, J.R. Hang on or run? Copepod mating versus predation risk in contrasting environments. Oecologia 2007, 153, 761-773. [CrossRef]

22. Ohtsuka, S.; Huys, R. Sexual dimorphism in calanoid copepods: Morphology and function. Hydrobiologia 2001, 453, 441-466. [CrossRef]

23. Ali, A.K.; Primicerio, R.; Folstad, I.; Liljedal, S.; Berge, J. Morphological correlates of mating frequency and clutch size in wild caught female Eudiaptomus graciloides (Copepoda: Calanoida). J. Plankton Res. 2009, 31, 389-397. [CrossRef]

24. Lee, C.E.; Bell, M.A. Causes and consequences of recent freshwater invasions by saltwater animals. Trends Ecol. Evol. 1999, 14, 284-288. [CrossRef]

25. Pennak, R.W. The Fresh-water Invertebrate Fauna: Problems and Solutions for Evolutionary Success. Am. Zool. 1985, 25, 671-687. [CrossRef]

26. Lutz, R.V.; Marcus, N.H.; Chanton, J.R. Hatching and viability of copepod eggs at two stages of embryological development: Anoxic/hypoxic effect. Mar. Biol. 1994, 119, 199-204. [CrossRef]

27. Hansen, B.W.; Drillet, G.; Kozmer, A.; Madsen, K.V.; Pedersen, M.E.; Sorensen, T.E. Temperature effects on Copepod egg hatching: Does acclimatization matter? J. Plankton Res. 2010, 32, 305-315. [CrossRef]

28. Kimmerer, W.J. Mortality estimates of stage structured populations must include uncertainty in stage duration and relative abundance. J. Plankton Res. 2015, 37, 939-952. [CrossRef]

29. Karlson, A.M.L.; Viitasalo-Frosen, S. Assimilation of ${ }^{14}$ C-labelled zooplankton benthic eggs by macrobenthos. J. Plankton Res. 2009, 31, 459-463. [CrossRef]

30. Gentleman, W.C.; Head, E.J.H. Considering non-predatory death in the estimation of copepod early life stage mortality and survivorship. J. Plankton Res. 2017, 39, 92-110. [CrossRef]

31. Dole, M.-J.; Galassi, D.M.P.; Marmonier, P.; Creuz Des Chatelliers, M. The Biology and Ecology of lotic microcrustaceans. Freshw. Biol. 2000, 44, 63-91. [CrossRef]

32. Belmonte, G.; Miglietta, A.M.; Rubino, F.; Boero, F. Morphological convergence of resting stages produced by planktonic organisms: A review. Hydrobiologia 1997, 335, 159-165. [CrossRef]

33. Stabili, L.; Miglietta, A.M.; Belmonte, G. Lysozyme-like and trypsin-like activities in the cysts of Artemia franciscana Kellog, 1906: Is there a passive immunity in a resting stage? J. Exp. Mar. Biol. Ecol. 1999, 237, 291-303. [CrossRef]

34. Redden, A.M.; Daborn, G.R. Viability of subitaneous copepod eggs following fish predation on egg-carrying calanoids. Mar. Ecol. Prog. Ser. 1991, 77, 307-310. [CrossRef]

35. Barnes, R.D. Invertebrate Zoology; Holt-Saunders International: Philadelphia, PA, USA, 1982; pp. $683-692$.

36. Kalinowska, K.; Karpowicz, M. Ice-on and ice-off dynamics of ciliates and metazooplankton in the Łuczański Canal (Poland). Aquat. Ecol. 2020, 54, 1121-1134. [CrossRef]

37. Frish, D.; Green, A.J. Copepods come in first: Rapid colonization of new temporary ponds. Fundam. Appl. Limnol. Arch. Hydrobiol. 2007, 168, 289-297. [CrossRef]

38. Gilbert, J.D.; De Vicente, I.; Ortega, F.; Jimenez-Melero, R.; Parra, G.; Guerrero, F. A comprehensive evaluation of the crustacean assemblages in southern Iberian Mediterranean wetlands. J. Limnol. 2015, 74, 169-181. [CrossRef]

39. Tonolli, V.; Tonolli, L. Osservazioni sulla biologia ed ecologia di 170 popolamenti zooplanctonici di laghi italiani di alta quota. Mem. Istituto Ital. di Idrobiol. 1951, 6, 53-136.

40. Andrei, M.; Gandolfi, G. I laghi di val Nure (Appennino piacentino). Boll. Di Pesca Piscic. E Idrobiol. 1965, 41, 61-142.

41. Marrone, F.; Castelli, G.; Barone, R.; Naselli-Flores, L. Ecology and distribution of calanoid copepods in Sicilian inland waters (Italy). Verh. Int. Ver. Limnol. 2006, 29, 2150-2156. [CrossRef]

42. Alfonso, G.; Belmonte, G.; Marrone, F.; Naselli-Flores, L. Does lake age affect zooplankton diversity in Mediterranean lakes and reservoirs? A case study from southern Italy. Hydrobiologia 2010, 653, 49-164. [CrossRef]

43. Alfonso, G.; Belmonte, G. Calanoida (Crustacea Copepoda) from the inland waters of Apulia (south-eastern Italy). J. Limnol. 2011, 70, 57-68. [CrossRef]

44. Marrone, F.; Petrusek, A.; Alfonso, G.; Arculeo, M. The diaptomid fauna of Israel (Copepoda, Calanoida, Diaptomidae), with notes on the systematics of Arctodiaptomus similis (Baird, 1859) and Arctodiaptomus irregularis Dimentman \& Por, 1985 stat. rev. Zool. Stud. 2014, 53, 74.

45. Toth, A.; Horvath, Z.; Vad, C.F.; Zsuga, K.; Nagy, S.A.; Boros, E. Zooplankton of the European soda pans: Fauna and conservation of a unique habitat type. Int. Rev. Hydrobiol. 2014, 99, 255-276. [CrossRef]

46. Evtimova, V.V.; Pandourski, I.S. Rotifers and lower crustaceans from South-western Iceland. Biodivers. Data J. 2015,4 , e7522. [CrossRef] [PubMed] 